\begin{tabular}{|c|c|c|}
\hline \multirow{3}{*}{$\begin{array}{l}\text { BENTHAM OPEN } \\
\text { CrossMark }\end{array}$} & $\begin{array}{c}\text { The Open Construction and Building } \\
\text { Technology Journal }\end{array}$ & $\begin{array}{l}\text { The Open } \\
\text { Construction \& Building } \\
\text { Trechnology lournal }\end{array}$ \\
\hline & Content list available at: www.benthamopen.com/ТОВСТЈ/ & \\
\hline & DOI: $10.2174 / 1874836801610010381$ & \\
\hline
\end{tabular}

RESEARCH ARTICLE

\title{
Flexible Design and Construction Strategies for Self-Help Housing in Botswana
}

\author{
K. Jobe* and C. J. K. Williams \\ Architecture \& Civil Engineering Department, University of Bath, Bath, United Kingdom
}

Received: April 30, 2015

Revised: June 11, 2015

Accepted: November 5, 2015

\begin{abstract}
In an effort to coordinate the housing schemes from different departments, Government of the Republic of Botswana took a decision to establish Single Housing Authority (SiHA) through a Presidential Cabinet Directive CAB20 (B) 2010 in July 2010. Previously, these schemes were designed and built by the local councils, with the help of the local builders and house owners. A review of the architect designed and contractor-led housing projects under this scheme, demonstrate the shortcomings of a standardized housing design approach and the need to develop a flexible design strategies that can respond to the inevitable changes associated with low-income housing. A qualitative case study research of Self-Help Housing Agency (SHHA)'s built houses was conducted in Mochudi (Botswana) to explore potential strategies of improving the current self-help housing design processes. Using case study examples from Mochudi, a systematic and flexible design framework is suggested as an economically viable approach to improve the quality of self-help housing design processes that reduce costly changes which are associated with the current government-funded housing schemes.
\end{abstract}

Keywords: Botswana, Flexible design, Low-income, Self-help housing, SiHA.

\section{INTRODUCTION}

In an effort to coordinate the housing schemes from different departments, Government of the Republic of Botswana took a decision to establish Single Housing Authority (SiHA) through a Presidential Cabinet Directive CAB20 (B) 2010 on July 2010 [1]. The Directive approved the following:

- The establishment of SiHA

- The transfer of all housing implementation programmes to Botswana Housing Corporation (BHC) as a single housing delivery vehicle

- Annual budgetary allocations to BHC to undertake the implementation of requisite low income housing and district housing projects.

SiHA is established under BHC to implement all the housing programmes which are mainly the Self-Help Housing Agency (SHHA) Loan Improvement and Turnkey Loan housing schemes [1]. BHC is a parastatal corporation solely owned by Botswana Government, established in 1971 [2]. BHC mandate is to provide affordable housing to Batswana but the proportion of houses provided by BHC has decreased from $4.6 \%$ in 2001 to $1.72 \%$ in 2011 [3]. Previously, the local council managed the SHHA schemes but are currently under SiHA for effective management and quality assurance. SHHA was meant to benefit the low-income communities who did not qualify for the BHC houses. Table $\mathbf{1}$ is a representation of SiHA, SHHA and self-funded housing initiatives. The table illustrates the hierarchic approach of SiHA and the non-hierarchic semi-autonomous approach of self- help builders.

This study will not contribute to the debate on the merits of a hierarchical and centralized approach to housing, but

\footnotetext{
* Address correspondence to this author at the Architecture \& Civil Engineering Department, University of Bath, BA2 7AY, Bath, United Kingdom; Tel: +44 (0)1225 385394; E-mail: kj303@bath.ac.uk
} 
rather discuss the design and construction strategies of these projects and how they can be improved ${ }^{1}$. However, it is important to note that one of the major benefits of the aided ${ }^{2}$ self-help housing programs of the 1970s was to place key decision-making responsibility in control of the inhabitants [4]. That means that the government's decision to transfer SHHA and turnkey housing programmes from the local councils to BHC, effectively took away the autonomy of the self-help housing initiatives.

The study has two main aims: firstly to demonstrate the importance of self-help housing as a socially and economically viable model for low-income communities in Botswana and secondly, explores the use of a flexible design framework to improve the quality of design for SiHA's low-income housing programmes at both local and national levels. In order to address the research aims, the paper will discuss conceptual framework for self-help housing and flexible design. This will form the basis for developing a flexible design framework.

\subsection{Self-Help Housing}

In housing research and practice, John F. C. Turner ${ }^{3}[4,5]$ is widely credited with self-help housing ${ }^{4}$ concept and incremental construction process, as an affordable approach to housing appropriate to the economies of third world countries [6]. The theory of self-help housing as developed by Turner [4, 5] in the 1950s and 1960s and promoted by international organizations in the 1970s, led to the concept of aided self-help housing [7 - 9]. The most important aspect of housing research developed over the years is that self-help housing and market enabling policies have been considered to be viable approaches to addressing housing challenges in the developing world [9 - 11].

Self-help housing, according to Paul Oliver [12], is by the occupants by themselves, without external professional intervention. Another related concept, housing as a process, as defined by Turner [4] places key decision-making responsibilities in the hands of the inhabitants. Turner [4] argues that self-help housing as a process can adequately meet people's housing needs and gives the dweller control over what is appropriate for them. Dwellers become active recipients or consumers of housing products resulting in houses that reflect their values and needs [4, 12]. He argues further that, "I will go beyond that to suggest that the ideal we should strive for is a model which conceives housing as an activity in which the users as a matter of economic, social and psychological common sense are the principal actors" [4]. Self-help housing is commonly practiced in Botswana as people buy and save materials for future building purposes, see Fig. (1).

Table 1. This diagram, modified from Turner 's [5] study of patterns of decision and control in housing in peru, shows similar studies for decisions-making processes for the single housing authority (SiHA), Self-Help housing agency (SHHA) and Self-funded (Owners) housing initiatives.

\begin{tabular}{|c|c|c|c|c|c|c|}
\hline \multicolumn{3}{|c|}{ Government Funded } & & \multicolumn{3}{|c|}{ Self-Help Housing } \\
\hline Plan & Constr. & Manage & & Plan & Constr. & Manage \\
\hline & & & SiHA & - & - & - \\
\hline & - & & SHHA & & & \\
\hline- & - & & Owners & & & \\
\hline
\end{tabular}

According to proponents of aided self-help housing “. . . aided self-help made sense not only on grounds of financial expediency, but also as an element of indigenous economic and cultural development" [9]. These views are also shared by [13], as he submits that informal settlements, which exclusively practice self-help housing, are responsive to the socio-economic conditions of the urban poor and are a viable solution to housing challenges in third world countries. As

\footnotetext{
${ }^{1}$ For a more developed discussion on this subject, see Nabeel Hamdi [49] as he stresses the importance of building social infrastructure as part of key factors in housing processes. Also see the work of John Turner on participatory approach and developing alternative economic models for lowincome housing $[4,5]$.

${ }^{2}$ Richard Harris [51] note that the term aided self-help housing was first applied in housing policy by the Swedish government in 1904, where funds are made available to local government to assist with the construction of low-income housing. He argues that the theory of aided self-help was only developed in the 1940 s.

${ }^{3}$ Turner developed the idea of self-help housing while studying illegal squatter settlements in Peru [4].

${ }^{4}$ Richard Harris [9], in A mixed message: The agents and forms of international housing policy, 1945-1973, traces the origins of 'aided self- help' to Jacob L. Crane, who is credited for coining the term in about 1948, and promoted the practice and theory of aided self-housing while at the Housing and Home Finance Agency in Washington, DC.
} 
housing challenges continues to increase in developing countries, advocates and critics of pro-poor housing policies and literature on housing research, call for a re-evaluation and return of aided or assisted self-help housing that was popular in the $1970 \mathrm{~s}^{5}$. In an attempt to develop pro-poor housing initiatives, the Botswana government established SiHA for the implementation of low-income housing projects around the country. Fig. (2) shows pictures of some of the houses developed under the SHHA Loan Improvement (see Fig. 2a) and the Turnkey Loan (see Fig. 2b) schemes. In studying housing in Botswana, it is important to briefly discuss the two organizations that were established by the government to provide housing to the citizens: the Botswana Housing Corporations (BHC) in 1970, and the Self-Help Housing Agency (SHHA) in 1973 [14]. BHC is a parastatal whose mission is to provide housing to both government employees and private individuals for rental or purchase [15]. SHHA is a housing scheme whose main objective is to provide decent shelter to rural villages and people in the low and middle income [14]. To qualify for SHHA, applicants' monthly income should be between P1 000.00 (approx. \$100) and P3 033.00 (approx. \$300) [14]. The SHHA scheme is now managed under SiHA by BHC. There are two low-income housing schemes under SiHA as outlined by the Department of Housing: Loan Improvement and Turnkey Loan schemes [14].

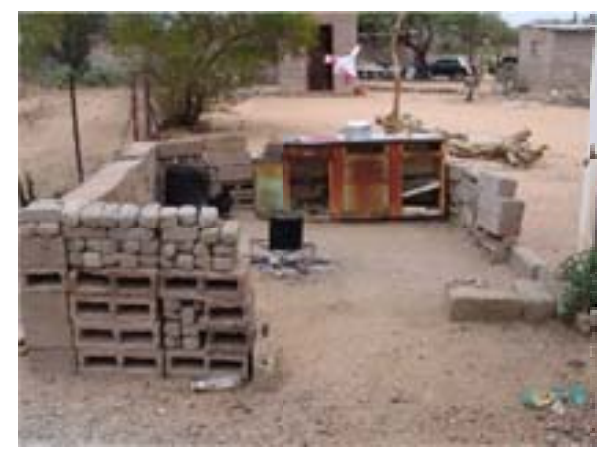

(a) Concrete block for future housing being used temporarily for an outdoor kitchen.

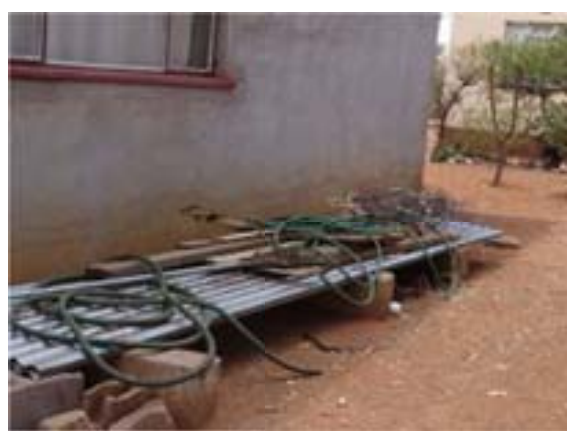

(b) Roof materials that have been kept here for years for future housing.

Fig. (1). A typical self-help housing process; where materials are saved for future housing development.

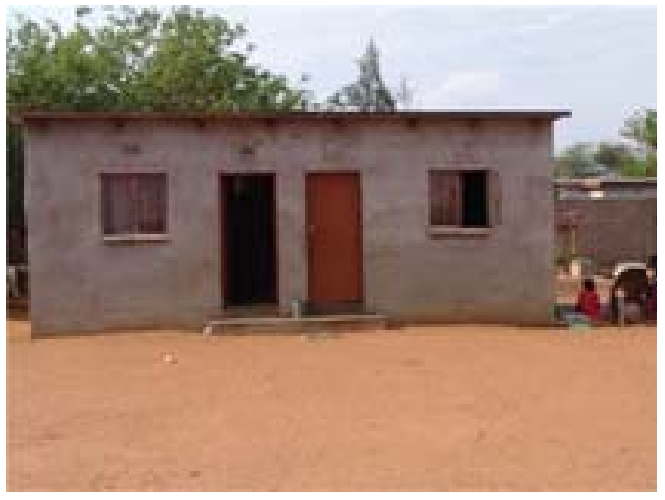

(a) SHHA Loan Improvement scheme house.

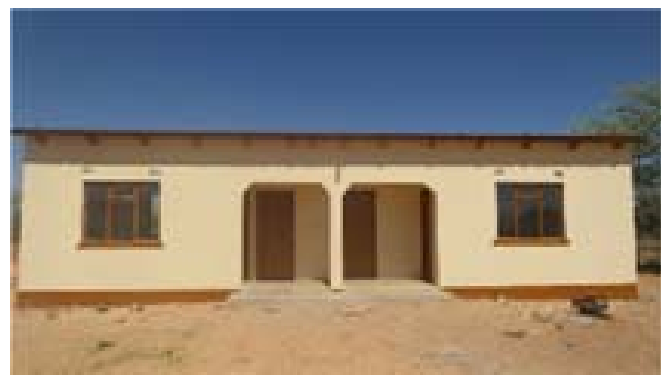

(b) Turn Key Loan scheme house.

Fig. (2). Houses built under the SHHA Loan improvement and turnkey loan schemes. Recipients are 'provided' with finished houses under the SiHA scheme which comes at a significant cost.

\footnotetext{
${ }^{5}$ The point is made by Bredenoord and van Lindert [52], in their call for housing policies that support self-build. Also see Budds et al. [53], discussing a policy framework developed by Sao Paulo municipal government, with emphasis on improving the quantity and quality of housing for low-income groups.
} 
- SHHA Loan Improvement is meant to finish, renovate or extend the existing structure. The maximum is P45, $000(\$ 4,500)$ with repayment period of 20 years at $0 \%$ interest, or $10 \%$ interest for defaulters.

- Turn Key Loan is P60, 000 (\$6,000), also with the same repayment conditions as above. In this scheme, houses are built by professional builders engaged by BHC on behalf of SiHA.

At policy level, the SHHA programmes have been successful, with more that $60 \%$ of the population having access to housing [15]. Despite its successes, there are critics that believe that the schemes are heavily subsidized with poor cost-recovery performance [15].

\subsection{Flexible Housing}

In many traditional societies in the past the process of designing and building of houses occurred simultaneously [16]. There was no separation of roles between the dwellers and the local builders in the design and building process. This is not to suggest that these societies did not design, but it was never a formal activity [17]. Peter Kellett [18] observes that occupation and construction took place simultaneously and the houses were usually in the process of dynamic change. Bryan Lawson [19] maintains that there is still a lot to learn from the traditional housing processes which are a lot cheaper and easier to build, offering more simpler and reliable solutions. Following this argument, one can consider the recent implementation of 'architect designed' and 'contractor-led' housing process by SiHA to be inappropriate for the economic and traditional practices commonly used in self-help housing. While we cannot deny the economic and social benefits of adopting industrial materials and building methods, it is more important to build houses that reflect Tswana's cultural identity and character. Fig. (3) is a good example of how pre-industrial traditional patterns (Fig. 3a) can inform organization of forms and spaces in contemporary houses (Fig. 3b).

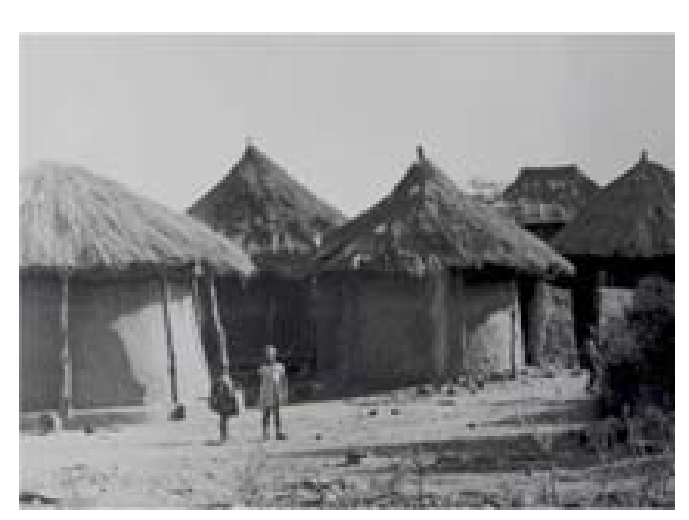

(a) Modular approach of the traditional Tswana houses. Source: National Archives and Records
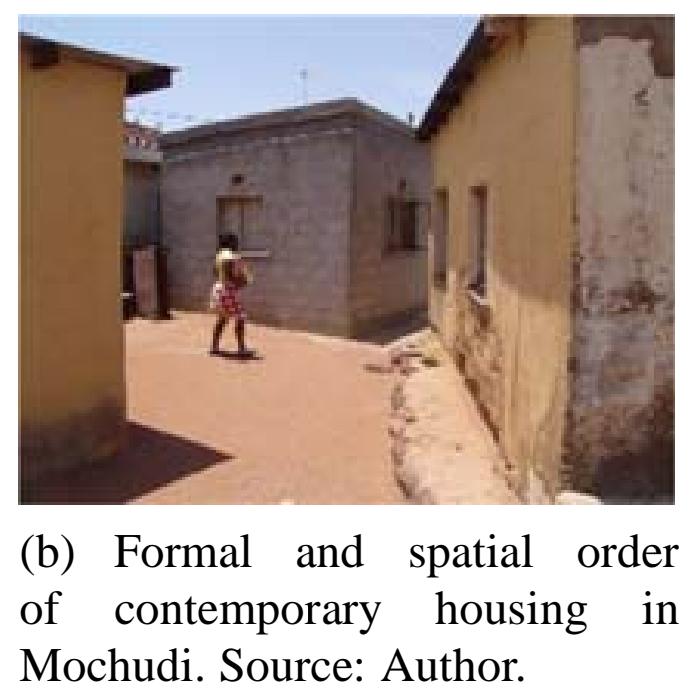

Fig. (3). Modular organization of building forms and spaces based on traditional tswana housing patterns.

Flexible design methods were developed as an alternative approach to traditional design methods and also to accommodate the needs of designers [20]. Flexible and adaptable housing are at times used interchangeably, but they have a different meaning [20]. Steven Groak [21], defines flexibility as a design process capable of different physical arrangements and adaptability as a building that can adapt to different social uses. The most appropriate definition of what is flexible housing, is the one given by Till and Schneider [20] that “. . . is housing that can adjust to changing needs and patterns, both social and technological. These changing needs may be personal (say an expanding family), practical (i.e. the onset of old age) or technological (i.e. the updating of old services). The changing patterns might be demographic (say the rise of single person household), economic (i.e. the rise of the rental market), or environmental (i.e. the need to update housing to respond to climate change)".

Architecture critics understandably oppose the idea of a logical or systematic design approach on the grounds of aesthetics and artistic freedom (For further discussions on these see for example Shove [22], and also Rapoport [23]). It 
is important to note that what is being developed here is not a house design but a flexible design framework that demonstrate a design process that local builders and users can use to design and build their houses effectively.

\section{CASE STUDY RESEARCH}

The current case study research is descriptive as it was set out to investigate and identify people's values, aspirations, and understand the current housing situation. It is also exploratory as it explores flexible design as housing strategy that places key design initiatives and greater decision-making control in the hands of the users. Following the definition given by Creswell [24], the aims of this research lends itself to a qualitative case study research methodological approach as the study involves design explorations, reflecting people's cultural preference; itself a social or human problem. Qualitative research, according to Richardson et al. [25], is ". . . a situated activity that locates the observer in the world. . . This means that qualitative research study things in their natural settings, attempting to make sense of, or interpret, phenomena in terms of meanings people bring to them."

Table 2. Population size and percent increase by census year and district. Source: National census 2001 and 2011.

\begin{tabular}{|l|l|l|l|l|}
\hline Census District & 2001 Population Increase & 2011 Population Increase & Population Increase & In Percent \\
\hline Gaborone & 186007 & 231592 & 45585 & 24.5 \\
\hline Francistown & 83023 & 98961 & 15938 & 19.2 \\
\hline Kgatleng & 73507 & 91660 & 18153 & 24.7 \\
\hline BOTSWANA & $\mathbf{1 , 6 8 0 , 8 6 3}$ & $\mathbf{2 , 0 2 4 , 9 0 4}$ & $\mathbf{3 4 4 , 0 4 1}$ & $\mathbf{2 0 . 5}$ \\
\hline
\end{tabular}

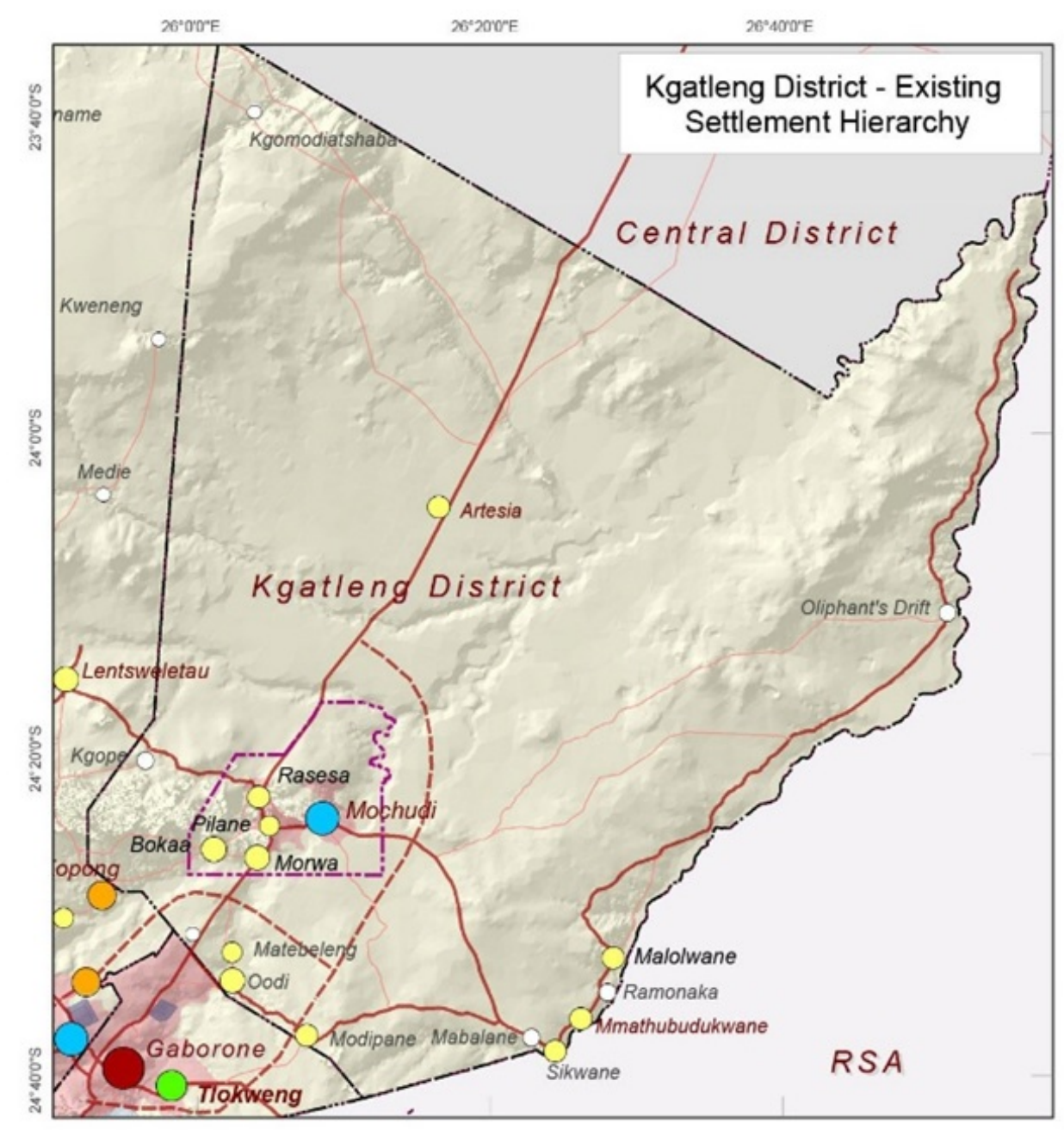

Fig. (4). Settlements hierachy in kgatleng district. Mochudi is the center of the district. Source: Department of surveys \& mapping (2013). Mochudi development plan (2007-2031). Technical report, ministry of lands \& housing. 
The empirical data presented in this paper were collected during fieldwork carried out in Mochudi (see Fig. 4), from September to December in 2013, as part of an ongoing PhD research. There are multiple houses that were purposefully selected as "cases" for the case study research. There is a large number of self-help housing projects designed and built by the people themselves and those from the state funded programmes in Mochudi which offered maximum variation for selection criteria. The variations in self-help housing strategies in Mochudi provided a good opportunity for a case study research that lead to an analytic generalization of the research analysis [26].

The case study research methodology for this study is approached within four thematic themes; that is the Physical System, the Spatial System, the Social System and the Technical/Construction System of self-help housing processes. However, this article only covers the spatial system (design) and construction system as they are appropriate for developing a flexible design framework discussed here.

Mochudi (in Kgatleng District), which is $40 \mathrm{~km}$ north east of the capital city, Gaborone, was chosen as a place to study because it provided a common case for studying housing processes in urban villages (see Figs. 4, 5). Also, there were logistical reasons for choosing Mochudi as it was easy to commute around the place, making the multiple case study research method easier to be cost-effective. Various data was collected such as documentary evidence from National Housing Policy, Housing Census Report, Development and Building Control Code, demographic reports; photographs from the field-work, archived plans, maps, aerial photographs; and from unstructured fieldwork interview.

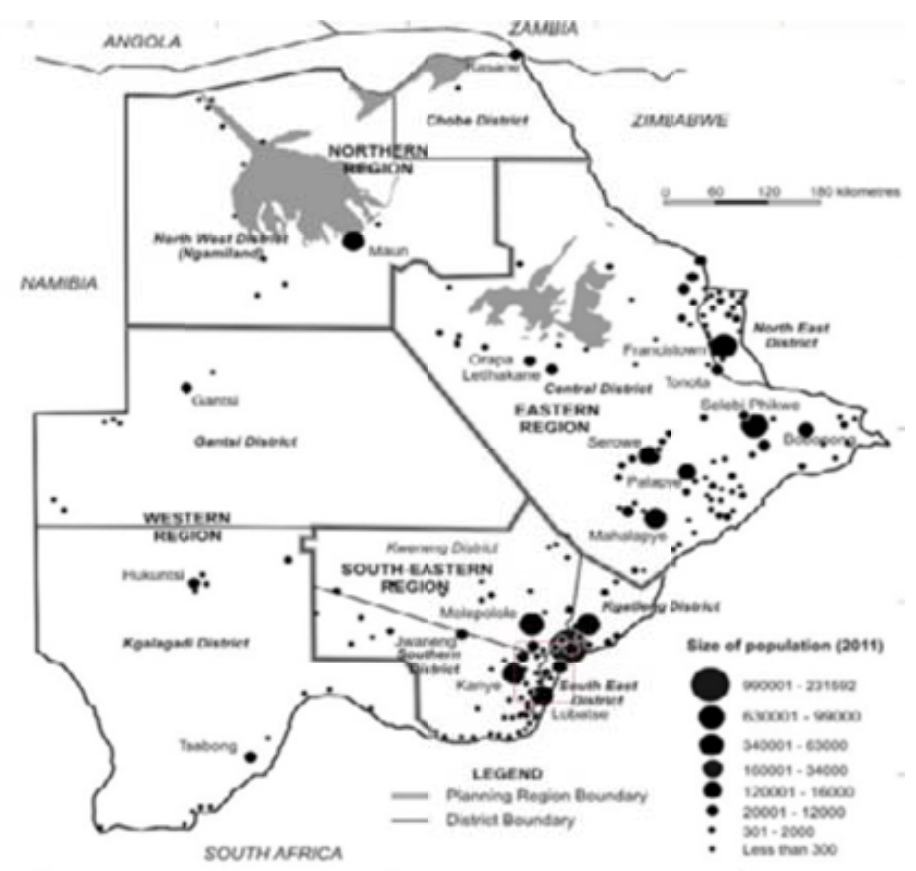

Fig. (5). Distribution of settlements by planning regions. The population is concentrated on the eastern side of botswana mainly because of the reliable rainfall, fertile soils and economic opportunities. Source: 2011 Population and housing census analytical report.

Mochudi, reflects a typical urban village in Botswana which experienced significant economic and population growth in the last couple of decades as shown in Table 2. Gaborone and Francistown are the two major cities in Botswana but the population increase in Kgatleng district (24.7\%), was comparatively more that in these two cities in the past decade [3]. The Southeastern Planning Region also recorded the highest population increase at $47.3 \%$ and highest population density at $13.8 / \mathrm{km}^{2}$ (see Fig. 5), [3]. The increase is attributed to urban dwellers who cannot afford high rental costs in cities turning nearby urban villages into dormitories. As a result, Mochudi has experienced a substantial housing transformations influenced by "modernization" and "globalization" mainly from people from outside. Housing transformations and rapid urbanization in urban villages in Botswana, especially those near cities is well documented (see for example Larsson [27, 28]). The map in Fig. (6) gives an overview of housing in Mochudi which is characterized by low-density detached one-storied buildings, spread irregularly in each household. 


\subsection{Design Strategy}

During my fieldwork research in Mochudi (by the first author), I observed many houses that were being modified; either being extended or refurbished. This was mainly due to a wide range of reasons such as a change in functional needs, aspirations, increase in family growth or availability of resources to build a better house. Unfortunately, these changes are mostly uncoordinated and unplanned. This often compromises any future developments leading to spaces of poor architectural quality. In addition, the houses deteriorate in value over-time, which negates the incremental investments that people make in an attempt to improve the quality of their houses [20]. This approach also lead to costly refurbishment and an increasing number of dilapidated buildings as observed by Kendall and Teicher [29], in their study of the residential construction industry in the UK.

According to the UN's Manual on Self-Help housing [30], the houses that are built under the SHHA schemes are referred to as "core-housing". This is mainly because the government's intentions to fund these "core-houses", is that the houses must be integrated to future permanent housing to be self-financed by the owners [30]. However, the integration of these houses into future housing is a challenge as they are not designed to accommodate changes at a minimum effort and costs. The other major challenges is the of lack of finance and technical design skills to effectively manage these changes.

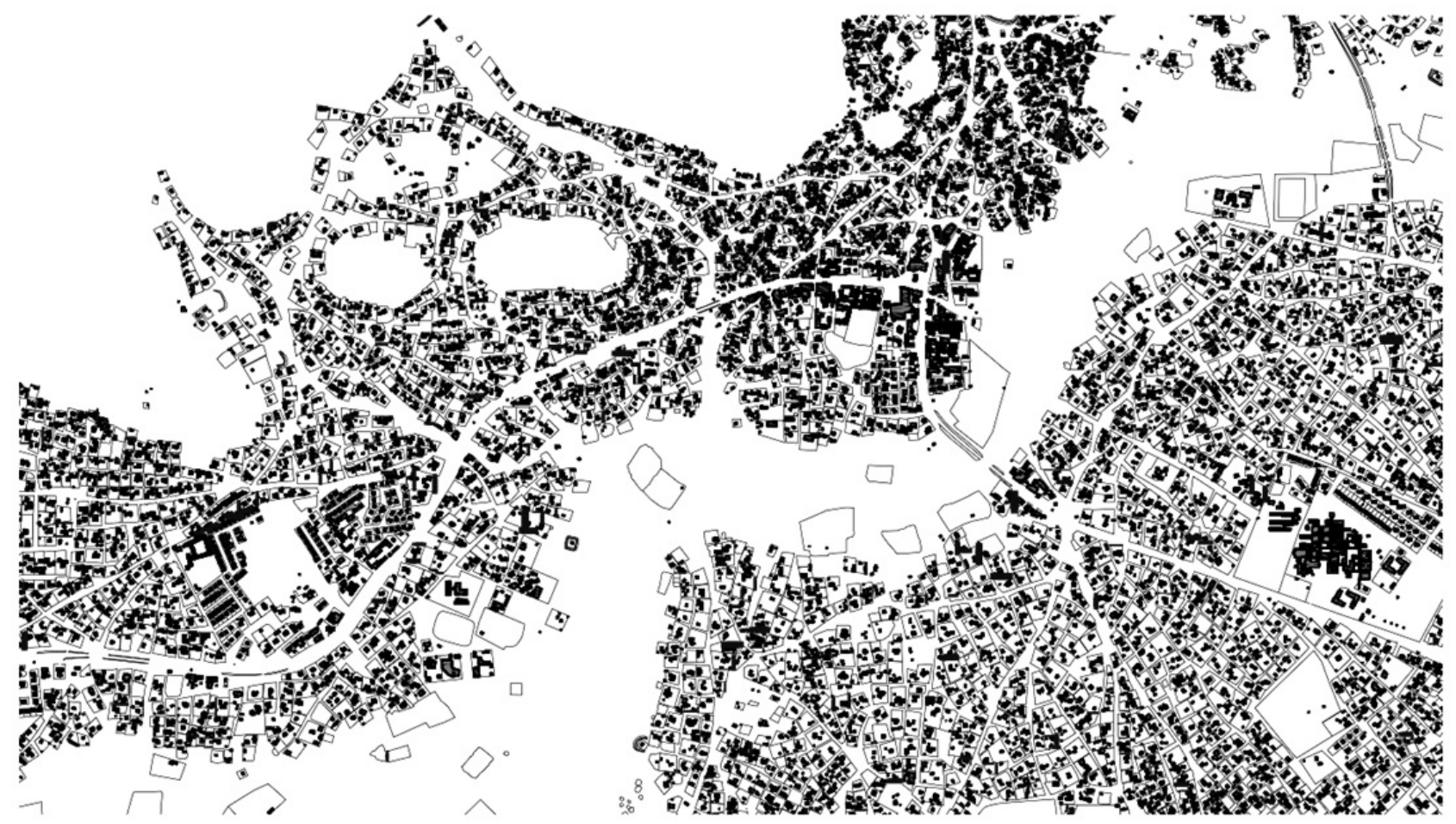

Fig. (6). Part of mochudi map showing building footprints.

In order to avoid design costs of designing for each and every SHHA applicants' individual house, the applicants have to choose from three plans that are 'professionally decided, professionally designed'. The standardized templates are also 'professionally built'. The plans are approximately $40 \mathrm{~m}^{2}$ (see Figs. 7, 8), which is quite small considering the number of people per household in low-income communities. According to the 2011 population census, almost twothird of the housing units are 1-2 small rooms [3]. Over time, owners' social needs and cultural values inevitably changes and they need to add or modify the existing house. Brand [31] stress the importance of a good design strategy that can easily accommodate future changes, that, ". . . a strategy is designed to encompass unforeseeable changing conditions. A good strategy ensures that, no matter what happens, you always have maneuvering room [31]".

The use of a uniform and standardized architect designed plan, built by contractors using high standard materials not locally available, increases the cost of houses significantly. The economic situation and cultural values of people in Mochudi varies and a standardized approach does not reflect such important characteristics. In his critique of standardized housing approach, Kendall [32] states that some household pay more for what they do not need while others have to settle for less than what they can afford. He proposes an open building design and construction strategy 
to address the challenges of income and household diversity [32].

\subsection{Construction Strategy}

As already noted, Botswana Housing Corporation (BHC) is appointed as project managers for the SHHA schemes, which were previously managed by the local councils and the owners. In order to deliver these schemes effectively, BHC adopted a contractor-led construction approach to meet its high building standard requirements. Under the current approach, the contractor is responsible of procuring materials, transporting materials to site, storage of materials on site and the actual building of the houses. Arguably, the quality of the built houses has improved compared to the previous scheme under the local councils, but at a significant cost to the government. Whether this approach has improved the social impact and process of housing will require further research.

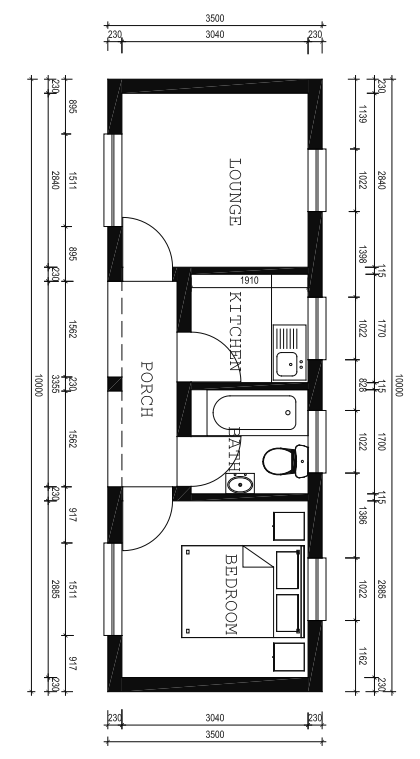

Fig. (7). A two-bedroom typology with a veranda. Source: Botswana Housing Corporation.

Fig. (9) is examples of a self-funded and incremental self-help housing process; where people continue to improve their houses while occupying them. Eventual the quality of the house reaches a satisfactory level that meets the dweller's needs. These self-initiated efforts by people can be supported both financially and technically for them to be effective. One way of providing support is developing a flexible design framework proposed in this study. The design framework assists the owners and local builders to develop design skills. Flexible design principles are based on ". . . industrial production, emerging technologies, improved logistics, and changing social values. . . [29]."

Table 3. Building materials used in housing in mochudi (\%).

\begin{tabular}{|c|c|c|c|c|c|}
\hline \multirow[t]{2}{*}{ Type of Material } & \multicolumn{5}{|c|}{ House Types } \\
\hline & Traditional & One room & Two room & Data Ched & Shack \\
\hline \multicolumn{6}{|l|}{ Exterior walls } \\
\hline Zinc sheets & - & - & - & - & 2 \\
\hline Mud bricks/blocks & 12 & 5 & 2 & 1 & 1 \\
\hline Concrete bricks/blocks & 0 & 13 & 32 & 4 & 1 \\
\hline \multicolumn{6}{|l|}{ Roof } \\
\hline Thatch/Straw & 12 & - & - & 0 & 0 \\
\hline Concrete Tiles & 0 & 0 & 8 & 2 & 0 \\
\hline Corrugated Iron/Zinc & 0 & 18 & 26 & 3 & 4 \\
\hline \multicolumn{6}{|l|}{ Floor } \\
\hline Cement & 3 & 15 & 18 & 5 & 0 \\
\hline Mud/Mud and Dung & 8 & 3 & 0 & 0 & 3 \\
\hline Brick/stones & 1 & 0 & 0 & 0 & 1 \\
\hline Surveyed houses & 12 & 18 & 34 & 5 & 4 \\
\hline
\end{tabular}


Traditionally, people in self-help communities built their houses with locally available materials. They built the houses with the help from local builders, family and at times members of the community would also help. Mainly in urban areas, it is common practice for owners to employ a paid builder to design and build their houses. However, from the case study research in Mochudi, more than $80 \%$ of people contributed labour in building their houses alongside a paid local builder. This is mainly because a majority of people in low-income communities are unemployed or hold irregular jobs to be able to afford a paid builder. Less than $20 \%$ of the houses were built entirely by a paid builder.

A detailed study of existing construction methods and available materials was carried out in the previous field-work in Mochudi. Table 3 is a summary of materials used for the houses that were studied in Mochudi. More than $70 \%$ of the roofs are corrugated galvanised metal, $14 \%$ are concrete tiles and the remaining $6 \%$ built of thatch. Corrugated galvanised metal is commonly used because it is robust, cheap and easy to use for self-help housing projects. $28 \%$ of the walls are built of mud bricks or blocks, and over $68 \%$ are built of concrete bricks or blocks. These bricks are easy to make in people's back-yard. The remaining $4 \%$ of walls built of corrugated galvanised metal are mainly shacks or temporary houses. Reinforced concrete is commonly used in housing projects as it readily available from local building material suppliers. However, it very expensive and many local builders compromise on the structural stability of concrete trying to reduce the costs. About $78 \%$ of the floors are cement, followed $19 \%$ of mud and dung, with the remaining $3 \%$ being a mixture of different materials such as bricks and stones.

Unfortunately, the quality of housing is still defined in terms of the use of industrial materials which does not reflect the identity of individuals or allow them to express their cultural values. One of the benefits of engaging users is that it leads to less expensive buildings as it reduces costly changes after construction [34, 35]. While it is clear that user participation is necessary and was practised in traditional architecture, the process has been lost in modern housing design.

This current work stresses the importance of a simplified and flexible design process, based on a modular system, as an alternative strategy to efficiently deliver the SHHA schemes. This systematic approach puts the user as the most important factor in housing and offers the possibilities for change in response to lifestyle changes and family growth [36]. The rigidity of the use of industrial materials, which reduces a house to a 'product'. The 2011 Population and Housing Analytical Report observes the changes in the use of industrial materials and that ". . this improvement is reflected in the decrease in the proportion of housing units classified as traditional type from $64 \%$ in 1991 to $22 \%$ in 2001 and $13 \%$ in 2011 [3].”

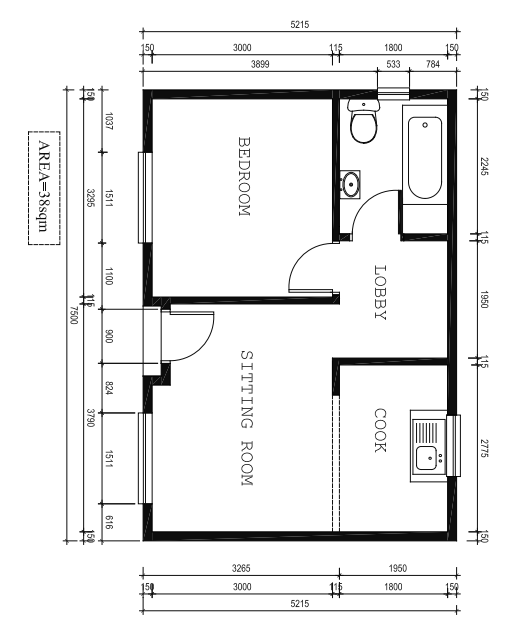

Fig. (8). A one-room typology. Source: Botswana Housing Corporation.

\section{PROPOSED FLEXIBLE DESIGN AND CONSTRUCTION FRAMEWORK}

There is a long history of debate in housing research about the importance of engaging users in the design of their housing. For example, Giancarlo De Carlo ${ }^{6}$ [33], an Italian architect who pursued social agenda in his projects, argued that building should give identity to individuals and allow them to express their cultural values. John Habraken [37, 38] developed a support system theory, an adaptable approach that allows design to transform over time [37, 38]. The support system depends on defined constraints, within which varables determine the form and spatial arrangement. The 
user engages with the design system to control the end product (the house), according to their taste, desires and functional requirements. Flexible process described here is influenced by the modular approach to housing in traditional Tswana architecture.

The following open design approach follows on Habraken's open design conceptual approach in housing. The open design approach organizes a house into hierarchical systems that can be constructed separately (see Fig. 10).

\subsection{Design Process}

The modular structural systems or support system theories and concepts, which is basically a system of primary and secondary structures, were used successfully by John Habraken [37 - 39] and Herman Hertzberger [35, 40] in housing projects. The modular structural system allows individuals to create their own spaces within a defined structure, which offered a simplified approach to change both the physical and non-physical aspect of housing. Charles Correa [41, 42] also developed a modular design system based on social and cultural patterns, as well as existing income profiles and existing plot sizes in India. This modular structural system reflects criticism offered by Alexander [43 - 45], Rapoport [46, 47], Venturi [48] and other prominent architecture critics. They rejected the notion of conventional design processes as being reductive and lacking complexities of real life. It was also a response to opposition of systematic design approach on the grounds of aesthetic and artistic freedom [36].

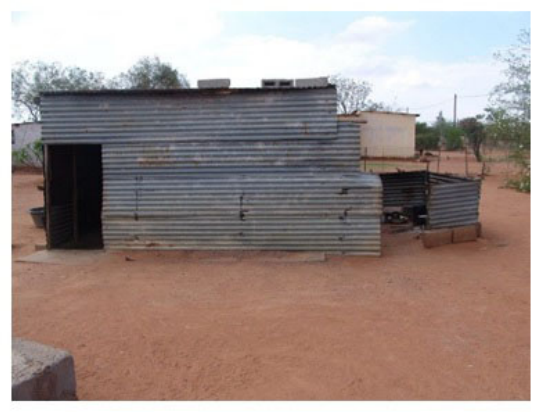

(a) A shack built of temporary materials.

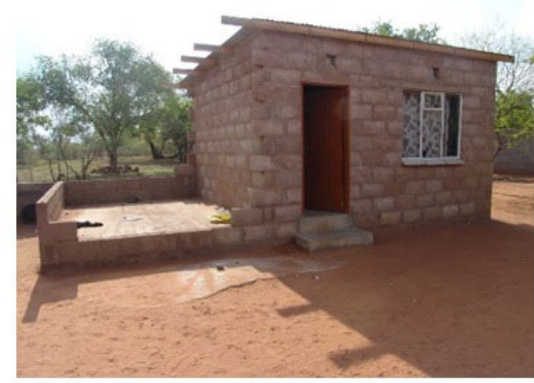

(b) One-room house built of concrete blocks.

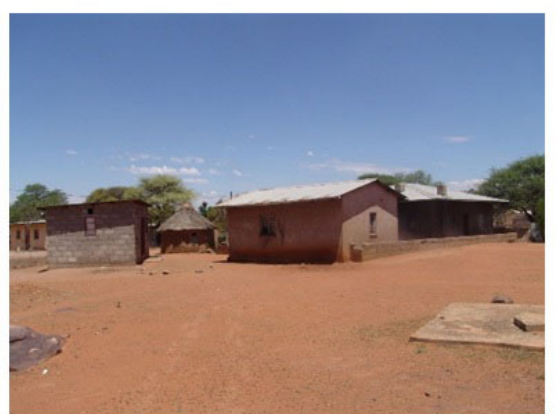

(c) Consolidated houses built progressively.

Fig. (9). The process of construction in self-help communities, beginning with a shack to consolidated finished houses built incrementally over the years.

To demonstrate how a flexible design strategy is made possible in housing, an open building conceptual approach is adapted and applied in one of the existing SHHA plans in the following design explorations. Following on Habraken's $[37,38]$ approach, An existing SHHA house plan is first divided into its subsystems as illustrated in Fig. (10).

Secondly, the SHHA plan is superimposed into a 15/30 band grid developed based on commonly used structural materials of $15 \mathrm{~cm}$ for interior walls and $30 \mathrm{~cm}$ for exterior structural walls in Botswana's construction industry (see Fig. 11).

Using the existing SHHA house types, we have proposed a variety of plans that can be achieved by adopting a simplified flexible design framework. There are many variations that can be achieved through this process and this was only a illustration of the open building concept. The design explorations are developed based on affodability and spatial needs of people living in self-help communities. This is an effective design approach that allows changes to be made with minimum effort and costs.

\subsection{Construction Process}

The most important aspect of the open building concept is that a house is divided into subsystems that can be constructed independent of each other. There is no room in this paper to go into details of how to develop technologies and materials suitable for this construction process illustrated in Table 4. However, this approach has been researched and applied in practice by John Habraken [37, 38] and Herman Hertzberger [35] amongst others. A further study is needed to develop technical details that can make this approach possible in Botswana's economic and social context.

\footnotetext{
${ }^{6}$ Giancarlo De Carlo [33] was a member of the CIAM (Congre's Inter-nationaux d'Moderne), who later set up a breakaway group of architects; Team $\mathrm{X}$, which included the Smithsons, Van Eyck, Erskine, Bakema and Candilis amongst others [54].
} 


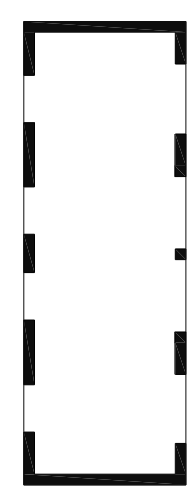

(a) The shell of the

house.

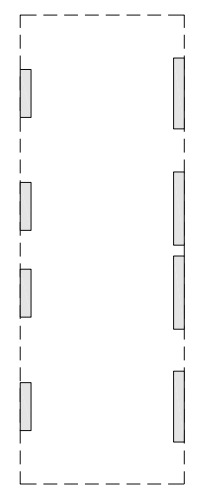

door

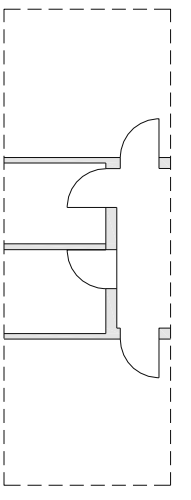

(c) Internal partition walls.

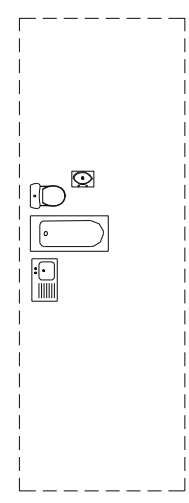

(d) Plumbing systems. (e) Movable furniture.

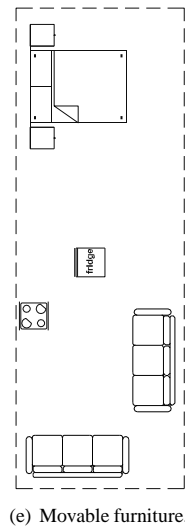

Fig. (10). An existing SHHA plan divided into its subsystems to demonstrate a conceptual approach of open building strategy.

This study proposes a construction process that places key decision making responsibilities in the hands of the dweller as developed by John Turner ${ }^{7}$ [5]. It is an attempt to simplify the design and construction processes with tools that are more predictable, controllable and flexible ${ }^{8}$. The design system is based on a defined set of rules that offer possibilities for growth and change with time. It is important to note that even though materials and building technology are standardized for efficiency, design can still be varied to reflect the various lifestyles and economic conditions of each owner with minimal effort and cost [37,44]. The major benefit of a flexible design framework is to avoid repetitive and monotonous housing as inhabitants play active role is the design and construction of their houses; a fundamental housing need [5]. The flexible construction process developed here is illustrated in Table $\mathbf{4}$ in the last row.

Table 4. In this proposed construction process, SiHA (government-funded) 'support' individuals to build houses for themselves rather than 'providing' them with finished houses. This can be achieved by placing key decision-making responsibilities in the hands of the owners and local builders.

SiHA

${ }_{7}^{7}$ John Turner [5] developed the idea of self-help housing in Peru, stressing the importance of what a house does to people's lives, not what a house is. ${ }^{8}$ Christopher Alexander [44, 55] and John Habraken [37, 38], separately developed important theories and concepts that design and building technology can easily be taught to local builders and owners if it is standard and simple. 
There are three major benefits of developing a design framework that focuses at a household scale as part policy development and housing initiatives. Firstly, the start-up costs are low and solutions can easily be appropriated or localized [49]. Secondly, centralized approaches to housing problems have proved to be inefficient both in costs and administration as housing challenges are diverse and unique in their nature [4]. Thirdly, a household is an important traditional form of social unit in a Botswana villages that needs to be empowered and nurtured [50].

\section{CONCLUSION}

The Government has a limited budget allocated for housing which cannot sustain 'providing' houses to people. Using examples from Mochudi, a case is made to develop a flexible design framework that allows the government to create an enabling environment as 'facilitators' or 'supporters' of the self-help housing initiatives that are already in common practice in low-income communities. This approach also helps change housing from a product-oriented approach to process-oriented processes. In exploring housing in Mochudi, the study demonstrates that the architectdesigned and contractor-led housing approach for the low-income communities shows little respect of the economic situation and social needs of the local people.

The development of a flexible design framework achieves the aims of this study. This approach focuses on userparticipation in the initial design process as essential to housing that is not only affordable but also socially appropriate. An efficient and systematic design approach will also save self-help housing dwellers and local builders from trial and error methods. Various dwelling typologies can easily be generated to reflect the diverse economic situation and social needs of people in low-income communities. The flexible design approach also maximizes potential for future additions as the economic and social needs of inhabitants' changes.

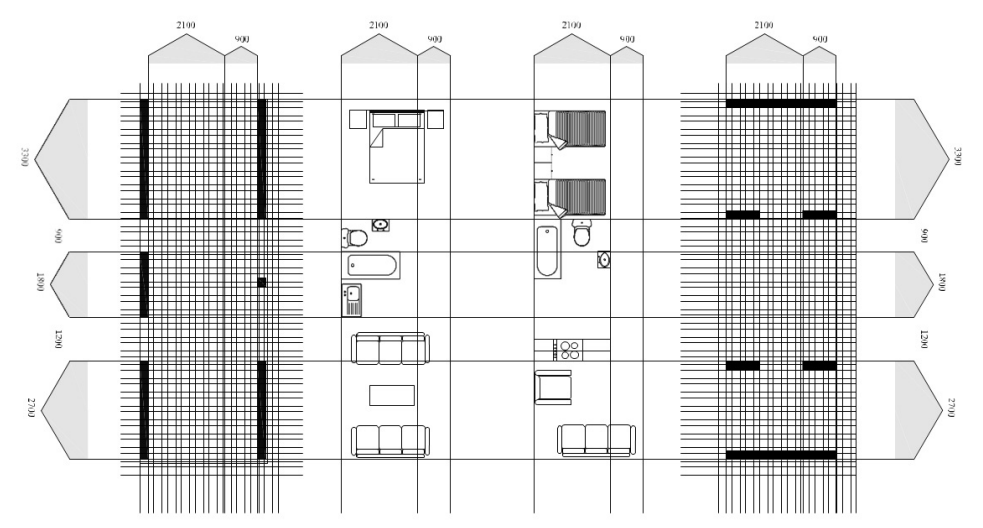

Fig. (11). The support systems and three major zones for placing major spaces in a flexible design process.

However, flexible design and user-centred design approaches also raises some important practical questions such as the role and responsibilities of the designer, the users and authorities ( $\mathrm{SiHA}$ ). These were considered secondary for the current research but merits further research.

\section{CONFLICT OF INTEREST}

The authors confirm that this article content has no conflict of interest.

\section{ACKNOWLEDGEMENTS}

This work is supported financially by Mashhad University of Medical Sciences.

\section{REFERENCES}

[1] The Republic of Botswana, Single Housing Authority. [Online]. Available from: http:// www.gov.bw/en/Ministries -Authorities/ Ministries/Ministry-of-Lands -and-Housing/Services/Services -and-Forms/Single-Housing -Authority-SiHA/, 2015.

[2] Botswana Housing Corporation, Government Housing Initiatives. [Online]. Available: http://www.bhc.bw/, 2015.

[3] Statistics Botswana, The 2011 Population and Housing Census Analytical Report, Government of Botswana, 2014.

[4] J.F. Turner, Housing by People: Towards Autonomy in Building Environments, Pantheon Books: New York, 1977.

[5] J.F. Turner, and R. Fichter, Freedom to build: Dweller control of the housing process, The Macmillan Company: New York, 1972. 
[6] R. Burgess, "Petty commodity housing or dweller control? A critique of John Turner's views on housing policy", World Dev., vol. 6, no. 9, pp. 1105-1133, 1978. [http://dx.doi.org/10.1016/0305-750X(78)90067-0]

[7] P.M. Ward, Self-Help Housing: A Critique, Mansell: London, 1982.

[8] D. Drakakis-Smith, The Third World City, Methuen: London, 1987. [http://dx.doi.org/10.4324/9780203456736]

[9] R. Harris, and C. Giles, "A mixed message: The agents and forms of international housing policy, 1945-1973", Habitat Int., vol. 27, no. 2, pp. 167-191, 2003. [http://dx.doi.org/10.1016/S0197-3975(02)00044-9]

[10] C. Pugh, "The changing roles of self-help in housing and urban policies, 1950-1996: Experience in developing countries", Third World Plann. Rev., vol. 19, no. 1, p. 91, 1997. [http://dx.doi.org/10.3828/twpr.19.1.68535555251w7183]

[11] R.E. Stren, "Housing Africa's urban poor", In: P. Amis, and P. C. Lloyd, Eds., Urban Housing in Africa. The Changing Role of Government Policy, Manchester University Press, 1990, no. 3, pp. 35-53.

[12] P. Oliver, Dwellings: The Vernacular House World Wide, Phaidon, 2010.

[13] G. Steyn, Sustainable African Settlement: Profiling a Vision, Tshwane University of Technology: Pretoria, South Africa, 2003.

[14] Self-Help Housing Agency. [Online]. Available from: http:// www.gov.bw/en/Ministries --Authorities/Local- Authorities/North- East-DistrictCouncil/Tools-and -Services/Services/Self -Help-Housing-Agency-- SHHA/, 2015

[15] A.C. Mosha, "Low-income access to urban land and housing in Botswana", Urban Forum, vol. 24, no. 1, pp. 137-154, 2013.

[16] B. Lawson, How Designers Think: The Design Process Demystified, Routledge, 2006.

[17] N. Habraken, The Appearance of the Form: Four Essays on the Position Designing Takes Between People and Things, Awater Press, Cambridge, 1988.

[18] P. Kellett, "Constructing Informal Places", In: S. Menin, Ed., Constructing Place: Mind and Matter, Routledge, 2003.

[19] B. Lawson, How Designers Think: The Design Process Demystified, Routledge, 2006.

[20] T. Schneider, and J. Till, Flexible Housing, Architectural press: London, 2007.

[21] S. Groak, The Idea of Building: Thought and Action in The Design and Production of Buildings, Taylor \& Francis, 2002.

[22] E. Shove, Social, Architectural and Environmental Convergence, Environmental Diversity in Architecture, 2004, pp. 19-30.

[23] A. Rapoport, "Facts and models", In: G. Broadbent, and A. Ward, Eds., Design Methods in Architecture, Lund Humphries: London, 1969, pp. 136-146.

[24] J.W. Creswell, Qualitative Inquiry and Research Design: Choosing Among Five Approaches, Sage Publications: Newbury park, CA, 2013.

[25] L. Richardson, "Writing: A method of inquiry", In: N.K. Denzin, and Y.S. Lincoln, Eds., Handbook of Qualitative Research, $3^{\text {rd }}$ ed. Thousand Oaks: CA, 2000, pp. 923-948.

[26] R. K. Yin, Case Study Research: Design and Methods, Sage Publications: Newbury Park, CA, 2014.

[27] A. Larsson, and V. Larsson, Traditional Tswana Housing. A Study in Four Villages in Eastern Botswana, Swedish Council for Building Research: Stockholm, 1983

[28] A. Larsson, Modernisation of Traditional Tswana housing: A Decade of Transformation, vol. 6. University of Lund, Lund Centre for Habitat Studies: Sweden, 1996.

[29] S.H. Kendall, and J. Teicher, Residential Open Building, Routledge, 2010.

[30] United Nations. Department of Economic and Social Affairs, Manual on Self-Help Housing, vol. 8. New York : United Nations, 1964.

[31] S. Brand, How Buildings Learn: What Happens After They are Built, Penguin Books: NY, 1994.

[32] S. Kendall, "Open building: an approach to sustainable architecture", J. Urban Technol., vol. 6, no. 3, pp. 1-16, 1999. [http://dx.doi.org/10.1080/10630739983551]

[33] G. De Carlo, "Architectures Public", In: P.B. Jones, D. Petresa, and J. Till, Eds., Architecture and Participation, Spon: Oxford, 2005.

[34] L. Kroll, and P. Blundell-Jones, The Architecture of Complexity, Batsford London, 1986.

[35] H. Hertzberger, Lessons for Students in Architecture, Rotterdum: 010 Publishers, 2005.

[36] P.B. Jones, "The Sheffield urban study project", Architec. Res. Q., vol. 7, no. 03, pp. 211-324, 2013.

[37] N.J. Habraken, and B. Valkenburg, Supports: An Alternative to Mass Housing, Architectural Press London, 1972.

[38] N.J. Habraken, and J. Teicher, The Structure of the Ordinary: Form and Control in the Built Environment, MIT press: London, 2000.

[39] N. John Habraken, "Design for flexibility", Build. Res. Inform., vol. 36, no. 3, pp. 290-296, 2008. [http://dx.doi.org/10.1080/09613210801995882] 
[40] T. Nakamura, Herman Hertzberger: 1959-1990, Architecture and Urbanism: Tokyo, 1991.

[41] C. Correa, Housing and Urbanisation, Thames \& Hudson: UK, 2000.

[42] K. Frampton, and C. Correa, Charles Correa, Thames \& Hudson: UK, 1996.

[43] C. Alexander, The Timeless Way of Building, vol. 1. Oxford University Press: UK, 1979.

[44] C. Alexander, The Production of Houses, vol. 4. Oxford University Press: UK, 1985.

[45] H. Neis, A new Theory of Urban Design, vol. 6. Oxford University Press: UK, 1987.

[46] A. Rapoport, The Meaning of the Built Environment: A Nonverbal Communication Approach; with a New Epiloque, University of Arizona Press, 1982.

[47] A. Rapoport, "Systems of activities and systems of settings", In: S. Kent, Ed., Domestic Architecture and the Use of Space: An Interdisciplinary Cross-Cultural Study, Cambridge University Press: Cambridge, 1990, pp. 9-20.

[48] R. Venturi, "Complexity \& Contradiction in Architecture", In: The Museum of Modern Art, vol. 1. 1977.

[49] N. Hamdi, The Placemaker's Guide to Building Community, Earthscan: London, 2010.

[50] G.J. Hardie, Tswana Design of House and Settlement: Continuity and Change in Expressive Space, Boston University, 1981.

[51] R. Harris, "The silence of the experts:aided self-help housing, 1939-1954", Habitat Int., vol. 22, no. 2, pp. 165-189, 1998. [http://dx.doi.org/10.1016/S0197-3975(97)00038-6]

[52] J. Bredenoord, and P. van Lindert, "Pro-poor housing policies: Rethinking the potential of assisted self-help housing", Habitat Int., vol. 34, no. 3, pp. 278-287, 2010. [http://dx.doi.org/10.1016/j.habitatint.2009.12.001]

[53] J. Budds, "Ensuring the right to the city: pro-poor housing, urban development and tenure legalization in Sao Paulo, Brazil", Environ. Urban., vol. 17 , no. 1 , pp. 89-114, 2005.

[54] B. Zucchi, and G. De Carlo, Giancarlo De Carlo, Butterworth- Heinemann, 1992.

[55] C. Alexander, Pattern Languages, vol. 2. Center for Environmental Structure, 1977.

(C) Jobe and Williams; Licensee Bentham Open.

This is an open access article licensed under the terms of the Creative Commons Attribution-Non-Commercial 4.0 International Public License (CC BY-NC 4.0) (https://creativecommons.org/licenses/by-nc/4.0/legalcode), which permits unrestricted, non-commercial use, distribution and reproduction in any medium, provided the work is properly cited. 